\title{
FORMULASI DAN UJI DAYA HAMBAT KRIM EKSTRAK ETANOL TEH HIJAU TERHADAP Propionibacterium acnes
}

\section{FORMULATION AND INHIBITION TEST OF ETHANOL EKSTRACT GREEN TEA CREAM ON Propionibacterium acnes}

\author{
Yayan Rizikiyan, Lela Sulastri, Sulistiorini Indriaty \\ Sekolah Tinggi Farmasi Muhammadaiyah Cirebon \\ Jalan Cideng Indah, No.3 Cirebon \\ Email: yayanrizikiyan@stfmuhammadiyahcirebon.ac.id
}

\begin{abstract}
ABSTRAK
Teh hijau merupakan tanaman yang kaya akan senyawa katekin, yang merupakan kandungan utama pada polifenol yang dimiliki teh yang berperan sebagai antioksidan. Pada penelitian ini ekstrak etanol teh hijau dengan konsentrasi $7 \%$ diformulasikan dalam dua formula. Formula I menggunakan elmugator Trietanolamin 2\% dan formula II menggunakan emulgator trietanolamin $1 \%$. Sedian krim diuji stabilitasnya dengan menggunakan metode cycling test, sebanyak 6 siklus. Evaluasi yang dilakukan meliputi pemeriksaan organoleptik, homogenitas, $\mathrm{pH}$, daya sebar, dan uji tipe krim. Pengamatan dilakukan pada hari ke-0 dan setiap setelah 1 siklus. Uji daya hambat dilakukan dengan dengan metode difusi cakram yaitu penentuan dengan cakram kertas yang dicelupkan ke dalam sediaan krim kemudian ditempatkan di atas permukaan media yang telah ditumbuhi bakteri kemudian diamkan selama 2 jam. Cawan petri diinkubasi pada suhu $37^{\circ} \mathrm{C}$ selama 24 jam kemudian zona hambat yang terbentuk diukur. Hasil penelitian menunjukan bahwa formula I dan formula II memiliki kestabilan yang baik dalam parameter uji homogenitas dan tipe krim sedangkan dalam parameter organoleptik, $\mathrm{pH}$, dan daya sebar tidak stabil. krim ekstrak etanol teh hijau dengan konsentrasi $7 \%$ mempunyai daya hambat yang ditunjukkan dengan rata-rata diameter hambat $1,35 \mathrm{~cm}$ terhadap Propionibacterium acnes. Secara statistik diameter hambat krim ekstrak teh hijau tidak berbeda signifikan dengan klindamisin gel $1 \%$ yaitu $1,76 \mathrm{~cm}$.
\end{abstract}

Kata kunci : Ekstrak etanol teh hijau, cycling test, uji daya hambat, difusi cakram, Propionibacterium acnes.

\begin{abstract}
Green tea is a plant rich in catechins, which is the main content of tea polyphenols that act as antioxidants. there is this study of green tea ethanol extract with $7 \%$ concentration formulated in two formulas. Formula I using elmugator Triaethanolamin $2 \%$ and formulas II using triaethanolamin $1 \%$. The stability of creams were tested using cycling test method, as much as 6 cycles. The Evaluation is including on organoleptic, homogenity, $\mathrm{pH}$, spreading ability, and the type of cream. The observation is made on the day 0 and every after 1 cycle. Inhibitory test conducted by disc diffusion method, determination with paper disc dipped in cream dosage then placed on the surface of bacteria overgrown medium then let stand for 2 hours. Petri dishes were incubated at $37^{\circ} \mathrm{C}$ for 24 hours then the inhibit zone formed was
\end{abstract}


measured. The results showed that the formula I and formula II had good stability in homogenity test parameters and cream types where as in organoleptic parameters, $\mathrm{pH}$, and spreading ability were unstable. A green tea of ethanol extract cream with a concentration of $7 \%$ has an inhibitory power indicated by an average of $1,35 \mathrm{~cm}$ inhibition diameter on Propionibacterium acnes. Statistically the green tea extract inhibitory diameter did not differ significantly with $1 \%$ clindamycin gel that is $1,76 \mathrm{~cm}$.

Keywords: Green tea of ethanol extract, cycling test, inhibitory test, disc diffusion, Propionibacterium acnes.

\section{PENDAHULUAN}

Jerawat adalah penyakit peradangan kelenjar sebasea yang sering dijumpai dan berkaitan dengan folikel rambut (disebut unit polisebasea). Bakteri penyebab jerawat antara lain Propionibacterium acnes, dan Staphylococcus epidermis.

Penggunaan bahan alam dapat menjadi salah satu alternatif dalam pengobatan jerawat. Pasien berjerawat yang menerima terapi antibiotik klindamisin, eritromisin, atau tetrasiklin sebagai pengobatannya cenderung menyebabkan peningkatan terjadinya infeksi saluran nafas atas bila dibandingkan dengan pasien berjerawat tanpa terapi antibiotik (Margolis et al., 2005).

Pada terapi acne, zat aktif katekin dalam teh hijau berfungsi sebagai antibakteri yang dapat digunakan untuk membunuh bakteri (Widyaningrum dkk, 2012). Ekawati dkk telah melakukan penelitian tentang aktivitas antibakteri dari ekstrak teh hijau pada tahun 2007. Pada penelitian tersebut konsentrasi ekstrak teh hijau dengan berbagai konsentrasi $(1 \%, 3 \%$, $5 \%, 7 \%$ dan 9\%) diformulasikan dalam sediaan krim. Hasil penelitian menunjukkan bahwa krim yang efektif sebagai krim antijerawat yaitu konsentrasi $7 \%$. Penggunaan teh hijau sebagai obat jerawat karena mengandung zat antioksidan katekin (polifenol) yang kuat, lebih kuat daripada vitamin E, C, dan $\beta$-karoten. Katekin adalah senyawa dominan dari polifenol daun teh (Camellia sinensis). Katekin terbukti dapat mengurangi produksi sebum, mencegah peradangan dan pertumbuhan bakteri di kulit.

Kosmetika antijerawat dapat diformulasikan dalam berbagai sediaan salah satunya adalah krim. Sedian krim dipilih karena memiliki beberapa keuntungan diantaranya lebih mudah diaplikasikan, lebih nyaman digunakan pada wajah, tidak lengket, dan mudah dicuci dengan air dibandingkan dengan sediaan salep, gel maupun pasta (Sharon, et al., dalam Iswindari, 2014). Formula I krim dibuat menggunakan trietanolamin 2\% berdasarkan literatur dari (Rowe, 2009). Menurut penelitian yang telah dilakukan oleh (Allen, 2009) mengatakan bahwa semakin banyak trietanolamin yang digunakan maka akan menurunkan konsistensi krim sehingga akan merusak stabilitas krim. Oleh karena itu konsentrasi trietanolamin 2\% menunjukkan stabilitas krim yang baik. Meskipun secara umum tidak meracuni bahan sediaan, trietanolamin bisa mengakibatkan reaksi hipersensitif atau iritasi pada kulit jika dimasukkan dalam formulasi sediaan secara berlebihan. Trietanolamin juga dapat bereaksi dengan pereaksi seperti tionilklorida dengan mengganti gugus hidroksi dengan halogen yang bersifat sangat toksik. Oleh karena itu pada formula II konsentrasi trietanolamin diturunkan menjadi $1 \%$.

Penelitian ini bertujuan untuk memformulasikan ekstrak etanol teh hijau dalam sediaan krim dengan emulgator trietanolamin $2 \%$ dan trietanolamin $1 \%$, dan menguji sabilitasnya. Selain itu untuk mengetaui daya hambat krim ekstrak etanol teh hijau konsentrasi 7\% terhadap bakteri Propionibacterium acnes, serta membandingkan dengan Klindamisin gel $1 \%$. 


\section{METODE PENELITIAN}

\section{Alat dan Bahan}

Alat yang digunakan dalam penelitian ini ialah Mixer; $\mathrm{pH}$ meter; Lemari pendingin; Oven; Rotary evaportor (IKA® RV 10 DZM n); Waterbath; Jangka sorong (Krisbow). Inkubator (Memert); jarum ose; kertas cakram $6 \mathrm{~mm}$; timbangan analitik (Radwag).

Bahan yang digunakan Serbuk teh hijau; Paraffin Liquidum (CV. Mustika Lab); Asam Stearat (CV. Mustika Lab); Trietanolamin (PT. Global); Adeps Lanae (CV. Mustika Lab); Sodium Benzoat (CV. Mustika Lab); Natrium Metabisulfit (CV. Mustika Lab); Etanol 96\% (CV. Mustika Lab); Aquadest (CV. Bratacem); nutrien agar (Oxoid); aquadest (Otsuka); Propionibacterium acnes; $\mathrm{NaCl}$ fisiologis $0,9 \%$; klindamisin gel $1 \%$.

\section{Jalannya Penelitian}

1. Pembuatan ekstrak etanol teh hijau

Serbuk simplisia teh hijau 500 gram dimasukkan ke dalam maserator, kemudian dibasahi dengan $3,750 \mathrm{ml}$ etanol $96 \%$, tutup bejana, diamkan selama 5 hari terlindung dari cahaya sambil terus diaduk. Setelah 5 hari campuran daun teh (Camellia sinensis) dengan etanol 96\% disaring kemudian diperas setelah itu ampasnya dibilas dengan sisa etanol $96 \%$ sebanyak $1.250 \mathrm{ml}$. Lalu maserat disimpan ke dalam bejana terlindung dari cahaya, diamkan selama 2 hari. Maserat lalu dipekatkan dengan rotary evaporator hingga sepertiga bagiannya. Ekstrak cair diuapkan di atas waterbath sampai diperoleh ekstrak kental teh hijau.

2. Formulasi krim ekstrak etanol teh hijau

a. Formula krim

Tabel I. Formulasi krim ekstrak etanol teh hijau

\begin{tabular}{lcccc}
\hline \multirow{2}{*}{\multicolumn{1}{c}{ Bahan }} & \multicolumn{4}{c}{ Jumlah (\%) } \\
\cline { 2 - 5 } & Basis I & Basis II & Formula I & Formula II \\
\hline Ekstrak Etanol Teh Hijau & - & - & 7 & 7 \\
Paraffin Liquidum & 25 & 25 & 25 & 25 \\
Asam Stearat & 14.5 & 14.5 & 14.5 & 14.5 \\
Trietnolamin & 2 & 1 & 2 & 1 \\
Adeps Lanae & 3 & 3 & 3 & 3 \\
Natrium Benzoat & 0,2 & 0,2 & 0,2 & 0,2 \\
Natrium Metabisulfit & 0,1 & 0,1 & 0,1 & 0,1 \\
Aquadest & ad $100 \mathrm{ml}$ & ad $100 \mathrm{ml}$ & ad $100 \mathrm{ml}$ & ad $100 \mathrm{ml}$ \\
\hline
\end{tabular}

Keterangan : Basis I : merupakan Formula I tanpa penambahan ekstrak Basis II : merupakan Formula II tanpa penambahan ekstrak Formula I : Formula krim dengan konsentrasi Trietanolamin 2\% Formula II : Formula krim dengan konsentrasi Trietanolamin 1\%

b. Pembuatan krim ekstrak etanol teh hijau dengan konsentrasi $7 \%$. Menimbang masing-masing bahan; Fase minyak (paraffin liquidum, asam stearat, dan adeps lanae) dilebur di atas waterbath pada suhu $60-70^{\circ} \mathrm{C}$; Larutkan fase air (trietanolamin, sodium benzoat, natrium metabisulfit dan aquadest), kemudian dipanaskan di atas waterbath pada suhu $60-70^{\circ} \mathrm{C}$; Fase minyak dituang ke dalam mixer aduk hingga homogen; Tambahkan fase air sedikit demi sedikit ke mixer sambil diaduk perlahan, kemudian aduk sampai terbentuk masa krim; Ekstrak kental teh hijau dimasukan sedikit demi sedikit ke dalam masa krim, kemudian diaduk sampai homogen. 
3. Uji stabilitas krim

Uji stabilitas dilakukan dengan metode cycling test. Krim disimpan pada suhu $4^{\circ} \mathrm{C}$ selama 24 jam setelah itu krim dipindahkan pada suhu $40^{\circ} \mathrm{C}$ selama 24 jam (disebut 1 siklus), dilakukan sebanyak enam siklus (Budiman, 2008). Pengamatan dilakukan pada hari ke 0 dan setiap setelah 1 siklus (hari ke 2, 4, 6, 8, 12) (Wulandari, 2016). Parameter yang diamati meliputi organoleptik, homogenitas, $\mathrm{pH}$, daya sebar, dan uji tipe krim.

a. Uji organoleptik dilakukan untuk melihat tampilan fisik sediaan dengan cara melakukan pengamatan terhadap bentuk, warna dan bau dari sediaan yang telah dibuat.

b. Uji homogenitas

Krim ditimbang 0,1 gram, diletakan pada kaca objek kemudian dilihat penyebaran partikel krim menunjukan struktur yang homogen.

c. Uji pH

Krim ditimbang 1 gram, diencerkan dengan $10 \mathrm{~mL}$ aquadestilla. Pengukuran $\mathrm{pH}$ dilakukan dengan menggunakan alat $\mathrm{pH}$ meter yang terlebih dahulu dikalibrasi dengan larutan dapar standar $\mathrm{pH} 4$ dan 7 biarkan hingga muncul $\sqrt{\mathrm{a}}$ yang menunjukkan nilai $\mathrm{pH}$ yang tetap di layar.

d. Uji daya sebar

Krim ditimbang 0,5 g, diletakkan diantara 2 lempeng gelas. Lempeng gelas pada bagian atas sebelumnya ditimbang terlebih dahulu kemudian diletakkan di atas sampel. Setelah 1 menit diameter sampel yang menyebar diukur pada berbagai sisi kemudian dirata-rata. Tambahkan beban sebesar 150 gram diamkan 1 menit dan diukur diameter krim yang menyebar. Daya sebar yang menunjukkan konsistensi semisolid yang sangat nyaman dalam penggunaannya adalah daya sebar yang berkisar antara 5-7 cm (Yulianti, 2015).

e. Uji tipe krim

Sejumlah Krim dimasukkan ke dalam wadah, kemudian diencerkan dengan air. Jika emulsi dapat diencerkan maka tipe emulsi adalah tipe m/a dan jika emulsi tidak dapat diencerkan maka tipe emulsi adalah tipe $\mathrm{a} / \mathrm{m}$.

4. Uji daya hambat

Krim yang stabil, diuji daya hambatnya menggunakan metode diffusi cakram. Kontrol positif dalam penelitian ini adalah gel antibiotik Klindamisin dengan konsentrasi $1 \%$, dan kontrol negatif berupa basis krim. Sebanyak $1 \mathrm{ml}$ suspensi bakteri diinokulasikan ke dalam media nutrient agar sebanyak $60 \mathrm{ml}$, kocok perlahan. Media nutrient agar dituangkan ke dalam 3 cawan petri masing-masing $20 \mathrm{ml}$, kemudian biarkan sampai dingin. Siapkan 5 kertas saring kemudian celupkan dalam sediaan krim ekstrak etanol teh hijau dengan konsetrasi 7\%, ekstrak etanol teh hijau, etanol 96\%, kontrol positif dan negatif diamkan selama 15 menit, kemudian tempatkan di atas permukaan media nutrien agar. Setelah itu dibiarkan selama 2 jam, lalu masukkan ke dalam inkubator pada $37^{\circ} \mathrm{C}$ selama 24 jam. Lihat dan ukur diameter hambatannya dengan menggunakan jangka sorong. Pembacaan hasil dilakukan setelah diinkubasi selama 24 jam dengan cara melihat daerah bening di sekeliling kertas saring sebagai daerah hambatan pertumbuhan bakteri Propionibacterium acnes. Diameter hambatan tersebut diukur dengan menggunakan jangka sorong.

\section{Analisis Data}

Pengolahan data dilakukan dengan mencatat hasil penelitian cycling test yang meliputi pengujian organoleptik, homogenitas, $\mathrm{pH}$, daya sebar, dan uji tipe krim. Hasil penelitian yang telah diolah dan dianalisa kemudian ditampilkan dalam bentuk tabel. Hasil pengujian daya hambat diolah secara statistik dengan menggunakan uji anova kemudian dilanjutkan dengan uji Post Hoc LSD 0,05. 


\section{HASIL DAN PEMBAHASAN}

Hasil uji organoleptik basis dan formula krim dengan metode cycling test dapat dilihat dalam Tabel II dan Tabel III.

Tabel II. Hasil pengamatan organoleptik basis krim

\begin{tabular}{|c|c|c|c|c|c|c|}
\hline \multirow{3}{*}{$\begin{array}{c}\text { Siklus } \\
\text { ke }\end{array}$} & \multicolumn{6}{|c|}{ Organoleptik } \\
\hline & \multicolumn{3}{|c|}{ Basis I } & \multicolumn{3}{|c|}{ Basis II } \\
\hline & Warna & $\mathrm{Bau}$ & Bentuk & Warna & $\mathrm{Bau}$ & Bentuk \\
\hline 0 & Putih & Tidak berbau & Semi padat & Putih & $\begin{array}{l}\text { Tidak } \\
\text { berbau }\end{array}$ & Semi padat \\
\hline 1 & Putih & Tidak berbau & Semi padat & Putih & $\begin{array}{l}\text { Tidak } \\
\text { berbau }\end{array}$ & Semi padat \\
\hline 2 & Putih & Tidak berbau & Semi padat & Putih & $\begin{array}{l}\text { Tidak } \\
\text { berbau }\end{array}$ & Semi padat \\
\hline 3 & Putih & Tidak berbau & Semi padat & Putih & $\begin{array}{l}\text { Tidak } \\
\text { berbau }\end{array}$ & Semi padat \\
\hline 4 & Putih & Tidak berbau & Semi padat & Putih & $\begin{array}{l}\text { Tidak } \\
\text { berbau }\end{array}$ & Semi padat \\
\hline 5 & Putih & Tidak berbau & Semi padat & Putih & $\begin{array}{l}\text { Tidak } \\
\text { berbau }\end{array}$ & Semi padat \\
\hline 6 & Putih & Tidak Berbau & $\begin{array}{l}\text { Semi } \\
\text { Padat }\end{array}$ & Putih & $\begin{array}{c}\text { Tidak } \\
\text { berbau }\end{array}$ & Semi padat \\
\hline
\end{tabular}

Keterangan : Basis I : merupakan Formula I tanpa penambahan ekstrak Basis II : merupakan Formula II tanpa penambahan ekstrak

Hasil uji organoleptik basis krim menunjukkan bahwa basis I dan II dari hari ke-0 sampai setelah siklus ke-6 tidak ada perubahan pada warna, bau, dan bentuknya.

Tabel III. Hasil pengamatan organoleptik krim

\begin{tabular}{|c|c|c|c|c|c|c|}
\hline \multirow{3}{*}{$\begin{array}{l}\text { Siklus } \\
\text { ke }\end{array}$} & \multicolumn{6}{|c|}{ Organoleptik } \\
\hline & \multicolumn{3}{|c|}{ Formula I } & \multicolumn{3}{|c|}{ Formula II } \\
\hline & Warna & $\mathrm{Bau}$ & Bentuk & Warna & $\mathrm{Bau}$ & Bentuk \\
\hline 0 & $\begin{array}{c}\text { Hijau } \\
\text { kecoklatan }\end{array}$ & Khas teh & Semi padat & $\begin{array}{c}\text { Hijau } \\
\text { kecoklatan }\end{array}$ & Khas teh & Semi padat \\
\hline 1 & $\begin{array}{c}\text { Coklat } \\
\text { kehijauan }\end{array}$ & Khas teh & Semi padat & $\begin{array}{c}\text { Hijau } \\
\text { kecoklatan }\end{array}$ & Khas teh & Semi padat \\
\hline 2 & $\begin{array}{c}\text { Coklat } \\
\text { kehijauan }\end{array}$ & Khas teh & Semi padat & $\begin{array}{c}\text { Coklat } \\
\text { kehijauan }\end{array}$ & Khas teh & Semi padat \\
\hline 3 & $\begin{array}{c}\text { Coklat } \\
\text { kehijauan }\end{array}$ & Khas teh & Semi padat & $\begin{array}{c}\text { Coklat } \\
\text { kehijauan }\end{array}$ & Khas teh & Semi padat \\
\hline 4 & $\begin{array}{c}\text { Coklat } \\
\text { kehijauan }\end{array}$ & Khas teh & Semi padat & $\begin{array}{c}\text { Coklat } \\
\text { kehijauan }\end{array}$ & Khas teh & Semi padat \\
\hline 5 & $\begin{array}{c}\text { Coklat } \\
\text { kehijauan }\end{array}$ & Khas teh & Semi padat & $\begin{array}{c}\text { Coklat } \\
\text { kehijauan }\end{array}$ & Khas teh & Semi padat \\
\hline 6 & $\begin{array}{c}\text { Coklat } \\
\text { kehijauan }\end{array}$ & Khas teh & Semi Padat & $\begin{array}{c}\text { Coklat } \\
\text { kehijauan }\end{array}$ & Khas teh & Semi padat \\
\hline
\end{tabular}

Keterangan : Formula I : krim dengan konsentrasi Trietanolamin 2\% Formula II : krim dengan konsentrasi Trietanolamin 1\% 
Pada krim formula I dan II, menunjukkan perubahan warna selama uji cycling test berlangsung. Pada krim Formula I terjadi perubahan setelah siklus ke-2, dari hijau kecoklatan, menjadi coklat kehijauan. Krim formula II berubah warna setelah siklus ke 4 . $\mathrm{Hal}$ ini terjadi karena suhu yang tinggi dalam Cycling test $\left(40^{\circ} \mathrm{C}\right)$ yang membuat polifenol dalam ekstrak semakin mudah teroksidasi dan semakin banyak konsentrasi polifenol di dalam krim semakin tampak akibat dari proses oksidasinya yang ditandai dengan warna kecoklatan (Setiawan, 2010). Selain itu, sifat kimia dari senyawa katekin yang terkandung di dalam teh hijau sensitif terhadap oksigen dan cahaya jika mengalami kontak langsung dengan udara terbuka (Syah, 2006).

Reaksi oksidasi dalam krim formula I dan II seharusnya tidak mudah terjadi, karena di dalam kedua formula sudah terkandung zat antioksidan Natrium metabisulfit. Dalam hal ini Natrium metabisulfit yang terkandung dalam Krim formula I dan II, kurang berperan dalam menahan reaksi oksidas. Berdasarkan data stabilitas natrium metabisulfit dalam Handbook of Pharmaceutical Excipient. Edisi VI (Rowe, 2009), diketahui bahwa natrium metabisulfit dapat teroksidasi secara perlahan dalam udara panas dan lembab.

Tabel IV. Hasil pengamatan homogenitas

\begin{tabular}{ccccc}
\hline Siklus ke- & \multicolumn{4}{c}{ Homogenitas } \\
\cline { 2 - 5 } & Basis I & Basis II & Formula I & Formula II \\
\hline 0 & Homogen & Homogen & Homogen & Homogen \\
1 & Homogen & Homogen & Homogen & Homogen \\
2 & Homogen & Homogen & Homogen & Homogen \\
3 & Homogen & Homogen & Homogen & Homogen \\
4 & Homogen & Homogen & Homogen & Homogen \\
5 & Homogen & Homogen & Homogen & Homogen \\
6 & Homogen & Homogen & Homogen & Homogen \\
\hline
\end{tabular}

Keterangan : Basis I : merupakan Formula I tanpa penambahan ekstrak Basis II : merupakan Formula II tanpa penambahan ekstrak Formula I : krim dengan konsentrasi Trietanolamin 2\% Formula II : krim dengan konsentrasi Trietanolamin 1\%

Hasil pengamatan homogenitas krim menunjukkan bahwa basis I, basis II, formula I dan formula II (Tabel IV), dari hari ke-0 sampai setelah siklus ke-6 menunjukkan susunan yang homogen.

Tabel V. Hasil pengamatan pH krim

\begin{tabular}{ccccc}
\hline Siklus ke- & \multicolumn{4}{c}{$\mathrm{pH}$} \\
\cline { 2 - 5 } & Basis I & Basis II & Formula I & Formula II \\
\hline 0 & 7,79 & 8,20 & 7,83 & 7,60 \\
1 & 8,39 & 8,34 & 7,86 & 7,72 \\
2 & 8,24 & 8,38 & 7,88 & 7,78 \\
3 & 8,36 & 8,40 & 7,89 & 7,68 \\
4 & 8,39 & 8,42 & 7,79 & 7,72 \\
5 & 8,05 & 8,12 & 7,62 & 7,42 \\
6 & 8,07 & 8.11 & 7,58 & 7,46 \\
\hline Rata-rata & $\mathbf{8 , 1 8}$ & $\mathbf{8 , 2 8}$ & $\mathbf{7 . 7 8}$ & $\mathbf{7 , 6 3}$ \\
\hline
\end{tabular}

Keterangan : Basis I : merupakan Formula I tanpa penambahan ekstrak Basis II : merupakan Formula II tanpa penambahan ekstrak Formula I : krim dengan konsentrasi Trietanolamin 2\% Formula II : krim dengan konsentrasi Trietanolamin $1 \%$ 
Hasil pengamatan $\mathrm{pH}$ basis dan formula krim (Tabel V) menunjukkan dari hari ke-0 sampai setelah siklus ke-6, baik basis maupun formula krim menunjukkan $\mathrm{pH}$ yang relatif stabil. Namun demikian, nilai $\mathrm{pH}$ basis maupun formula krim tersebut tidak memenuhi syarat $\mathrm{pH}$ kulit $(4,5-6,5)$.

Hasil pengamatan daya sebar basis dan formula krim dapat dilihat dalam Tabel VI. Daya sebar ditunjukkan dengan rata-rata diameter sebar. Hasil pengamatan daya sebar menunjukkan basis maupun formula krim mempunya daya sebar yang relatif stabil antara $3,94-4,70 \mathrm{~cm}$. Nilai tersebut tidak memenuhi persyaratan daya sebar untuk sediaan semisolid. Daya sebar yang sangat nyaman dalam penggunaannya adalah yang berkisar antara 5-7 cm (Yulianti, 2015). Besarnya nilai daya sebar menunjukkan konsistensi dari sediaan krim yang dibuat. Semakin padat suatu sediaan krim, makan daya sebarnya akan semakin kecil.

Tabel VI. Hasil pengamatan daya sebar krim

\begin{tabular}{ccccc}
\hline \multirow{2}{*}{ Siklus ke- } & \multicolumn{4}{c}{ Diameter Sebar $(\mathrm{cm})$} \\
\cline { 2 - 5 } & Basis I & Basis II & Formula I & Formula II \\
\hline 0 & 3,80 & 4,27 & 4,52 & 4,01 \\
1 & 4,90 & 4,26 & 4,73 & 3,66 \\
2 & 5,13 & 4,77 & 5,02 & 4,32 \\
3 & 5,01 & 4,58 & 4,31 & 3,96 \\
4 & 4,74 & 3,96 & 4,22 & 3,89 \\
5 & 4,90 & 5,53 & 4,34 & 4,07 \\
6 & 4,45 & 4,39 & 4,32 & 3,72 \\
\hline Rata-rata & $\mathbf{4 , 7 0}$ & $\mathbf{4 , 5 4}$ & $\mathbf{4 , 4 9}$ & $\mathbf{3 , 9 4}$ \\
\hline
\end{tabular}

Keterangan : Basis I : merupakan Formula I tanpa penambahan ekstrak Basis II : merupakan Formula II tanpa penambahan ekstrak Formula I : krim dengan konsentrasi Trietanolamin 2\% Formula II : krim dengan konsentrasi Trietanolamin 1\%

Hasil pengamatan tipe krim basis dan formula krim dapat dilihat dalam Tabel VII. Uji tipe krim bertujuan untuk melihat ada atau tidaknya fenomena inversi fase (perubahan fase) dari minyak dalam air menjadi air dalam minyak ataupun sebaliknya (Nabiela, 2013).

Tabel VII. Hasil pengamatan tipe krim

\begin{tabular}{ccccc}
\hline Siklus ke- & \multicolumn{4}{c}{ Tipe Krim } \\
\cline { 2 - 5 } & Basis I & Basis II & Formula I & Formula II \\
\hline 0 & $\mathrm{a} / \mathrm{m}$ & $\mathrm{a} / \mathrm{m}$ & $\mathrm{a} / \mathrm{m}$ & $\mathrm{a} / \mathrm{m}$ \\
1 & $\mathrm{a} / \mathrm{m}$ & $\mathrm{a} / \mathrm{m}$ & $\mathrm{a} / \mathrm{m}$ & $\mathrm{a} / \mathrm{m}$ \\
2 & $\mathrm{a} / \mathrm{m}$ & $\mathrm{a} / \mathrm{m}$ & $\mathrm{a} / \mathrm{m}$ & $\mathrm{a} / \mathrm{m}$ \\
3 & $\mathrm{a} / \mathrm{m}$ & $\mathrm{a} / \mathrm{m}$ & $\mathrm{a} / \mathrm{m}$ & $\mathrm{a} / \mathrm{m}$ \\
4 & $\mathrm{a} / \mathrm{m}$ & $\mathrm{a} / \mathrm{m}$ & $\mathrm{a} / \mathrm{m}$ & $\mathrm{a} / \mathrm{m}$ \\
5 & $\mathrm{a} / \mathrm{m}$ & $\mathrm{a} / \mathrm{m}$ & $\mathrm{a} / \mathrm{m}$ & $\mathrm{a} / \mathrm{m}$ \\
6 & $\mathrm{a} / \mathrm{m}$ & $\mathrm{a} / \mathrm{m}$ & $\mathrm{a} / \mathrm{m}$ & $\mathrm{a} / \mathrm{m}$ \\
\hline
\end{tabular}

Keterangan : Basis I : merupakan Formula I tanpa penambahan ekstrak Basis II : merupakan Formula II tanpa penambahan ekstrak Formula I : krim dengan konsentrasi Trietanolamin 2\% Formula II : krim dengan konsentrasi Trietanolamin 1\% 
Pengujian tipe krim dilakukan dengan metode pengenceran, metode ini didasarkan pada kelarutan emulsi dalam cairan yang menyusun fase kontinyu (Shovyana, 2013). Hasil pengamatan uji tipe krim dari hari ke-0 sampai setelah siklus ke-6 pada basis maupun pada formula krim merupakan tipe emulsi A/M.

Pengujian daya hambat krim ekstrak etanol menggunakan salah satu formula, karena karena konsentrasi ekstrak pada formula I sama dengan formula II, yaitu 7\%. Berdasarkan hasil pengamatan hasil uji stabilitas dengan metode cycling test dengan parameter di atas, formula I mempunyai kesetabilan yang relatif lebih baik dari formula II, oleh karena itu krim formula I digunakan pada pengujian daya hambat. Hasil uji daya hambat krim ekstrak Teh Hijau dengan Konsentrasi 7\% terhadap bakteri Propionibacterium acnes dapat dilihat pada tabel VIII. Krim ekstrak etanol teh hijau dengan konsentrasi $7 \%$ memiliki nilai ratarata diameter hambat $1,35 \mathrm{~cm}$. Nilai tersebut berada di atas rata-rata diameter hambat kontrol negatif dan di bawah kontrol positif. Kontrol negatif (basis krim) 0,6 cm dan kontrol positif (klindamisin) rata-rata $1,76 \mathrm{~cm}$. Hal ini menunjukkan bahwa krim ekstrak etanol teh hijau mempunyai aktivitas antibakteri terhadap Propionibacterium acnes. Rata-rata diameter hambat basis dan etanol 96\% sama besar dengan dimeter cakramnya yaitu 0,6 cm, hal ini menunjukkan bahwa keduanya tidak memberikan daya hambat terhadap Propionibacterium acnes.

Tabel VIII. Diameter daerah hambat krim ekstrak etanol teh hijau dengan konsentrasi 7\% terhadap bakteri Propionibacterium acnes

\begin{tabular}{ccccc}
\hline \multirow{2}{*}{ Replikasi } & \multicolumn{4}{c}{ Diamater Hambat $(\mathrm{cm})$} \\
\cline { 2 - 5 } & Kontrol (-) & Kontrol (+) & Etanol 96\% & Krim teh hijau \\
\hline 1 & 0,6 & 1,79 & 0,6 & 1,64 \\
2 & 0,6 & 1,61 & 0,6 & 1,36 \\
3 & 0,6 & 1,89 & 0,6 & 1,06 \\
\hline Rata-rata & $\mathbf{0 , 6}$ & $\mathbf{1 , 7 6}$ & $\mathbf{0 , 6}$ & $\mathbf{1 , 3 5}$ \\
\hline
\end{tabular}

Hasil uji Post Hoc LSD 0,05 menunjukkan bahwa ada perbedaan signifikan antara kelompok krim ekstrak teh hijau dengan kelompok basis dan etanol $96 \%$.

Tabel IX. Hasil uji post hoc LSD 0,05

\begin{tabular}{ccl}
\hline Kelompok & Hasil & \multicolumn{1}{c}{ Kesimpulan } \\
\hline $\begin{array}{c}\text { Krim ekstrak teh hijau } \\
\text { - Kontrol negatif }\end{array}$ & $\begin{array}{c}\mathrm{P}=0,032 \\
<0,05\end{array}$ & $\begin{array}{l}\text { Ada perbedaan signifikan antara kelompok krim } \\
\text { ekstrak teh hijau dengan kelompok kontrol } \\
\text { negatif. }\end{array}$ \\
$\begin{array}{c}\text { Krim ekstrak teh hijau } \\
\text { - Kontrol positif }\end{array}$ & $\begin{array}{c}\mathrm{P}=0,206 \\
>0,05\end{array}$ & $\begin{array}{l}\text { Tidak ada perbedaan signifikan antara kelompok } \\
\text { krim ekstrak teh hijau dengan kelompok kontrol } \\
\text { positif. }\end{array}$ \\
$\begin{array}{c}\text { Krim ekstrak teh hijau } \\
\text { - Etanol 96\% }\end{array}$ & $\begin{array}{c}\mathrm{P}=0,032 \\
\text { Ada perbedaan signifikan antara kelompok krim } \\
\text { ekstrak teh hijau dengan kelompok etanol 96\% }\end{array}$ \\
\hline
\end{tabular}

Tabel di atas menujukkan bahwa tidak ada perbedaan yang signifikan antara krim ekstrak teh hijau dengan kontrol positif (klindamisin). Ada perbedaan signifikan antara kelompok krim ekstrak teh hijau dengan kelompok kontrol negatif, etanol 96\%, dan ekstrak teh hijau. Artinya walaupun rata-rata diameter hambat krim ekstrak etanol teh hijau lebih kecil dari 
pada klindamisin gel $1 \%$, tetapi secara statistik daya hambatnya hampir sama dengan klindamisin gel $1 \%$.

\section{KESIMPULAN}

Krim ekstrak etanol teh hijau $7 \%$ dengan emulgator trietanolamin $2 \%$ relatif lebih stabil dibandingkan krim ekstrak etanol teh hijau dengan konsentrasi 7\% dengan emulgator trietanolamin 1\%. Krim ekstrak etanol teh hijau 7\% dengan emulgator trietanolamin $2 \%$ mempunyai daya hambat terhadap Propionibacterium acnes yang ditunjukan dengan ratarata diameter hambat $1,35 \mathrm{~cm}$.

\section{DAFTAR PUSTAKA}

Alfath, A.R. 2012. Formulasi Sediaan Krim Ekstrak Etanolik Buah Mahkota Dewa (Phaleria macrocarpa (Scheff) Boerl.) dengan Basis A/M dan M/A. Skripsi.

Allen, L. V., 2009. In Rowe, R. C., P. J. Sheskey., M. E. Quinn. Handbook of Pharmaceutical Excipients, 6th. Pharmaceutical Press and American Pharmacists Association, USA.

Brook, G.F., Butel, J.S., dan Morse, S.A. 2005. Mikrobiologi Kedokteran. Jakarta: Salemba Medika.

Corwin, E.J. 2009. Buku Saku Patofisiologi. Edisi III. Jakarta: EGC.

Dini, A.A. 2015. Formulasi Sediaan Skin Cream Aloe Vera (Aloe barbadensis): Evaluasi Fisik dan Stabilitas Fisik Sediaan. Skripsi.

Djajadisastra, Joshita dan Fauzia, S.F. 2014. Uji Aktivitas Antioksidan Sediaan Krim Ekstrak Daun Teh Hijau dan Krim Ekstrak Daun Teh Putih (Camellia sinensis. L). Skripsi.

Ekawati, S.K., Murrukmihadi.M., dan Wiyaningrum, N. 2012. Pengaruh Konsentrasi Ekstrak Etanolik Daun Teh Hijau (Camellia sinenis) dalam Sediaan Krim Terhadap Sifat Fisik dan Aktivitas Antibakteri. Jurnal Penelitian Kedokteran. Vol 4 No. 2.

Heroniaty. 2012. Sintesis Senyawa Dimer Katekin Dari Ekstrak Teh Hijau dengan Menggunakan Katalis Enzim Peroksidase Dari Kulit Bawang Bombay (Allium cepa L.). Tesis.

Hidayatullah, M. E. 2015. Senyawa Metabolit Sekunder (Catechin). Skripsi.

Iswindari, D. 2014. Formulasi dan Uji Aktivitas Antioksidan Krim Rice Bran Oil. Skripsi.

Karina, A. 2008. Pemanfaatan Jahe (Zingiber officinaale Rosc.) dan Teh hijau (Camellia sinensis) dalam Pembuatan Selai Rendah Kalori dan Sumber Antioksidan. Skripsi.

Maisarah, N.L., Pakki, E., Sartini dan Tayeb, R. 2009. Formulasi dan Evaluasi Kestabilan Fisik Krim Antioksidan Ekstrak Biji Kakao (Theobroma cacao L.). Majalah Farmasi dan Farmakologi. Vol. 13 No. 2 (ISSN : 1410 - 7031).

Nabiela, W. 2013. Formulasi Emulsi Tipe M/A Minyak Biji Jinten Hitam (Nigella sativa L,.). Skripsi.

Rohdiana, D dan Shabri. 2016. Optimasi dan karakterisasi ekstrak polifenol teh hijau dari berbagai pelarut. Jurnal Penelitian Teh dan Kina, (19)1, 2016: 57-66.

Rowe, R.C. 2009. Handbook of Pharmaceutical Excipient Edisi VI. Pharmaceutical Press American Pharmacists Association. London: Pharmaceutical Press. 
Setiawan, T. 2010. Uji Stabilitas Fisik dan Nilai SPF Krim Tabir Surya Yang Mengandung Ekstrak Daun Teh Hijau (Camellia sinensis L,.), Oktil Metoksisinamat dan Titanium Dioksida. Skripsi.

Shovyana, H.H dan Zulkarnain, A.K. 2013. Stabilitas Fisik dan Aktivitas Krim W/O Ekstrak Etanolik Buah Mahkota Dewa (Phaleria macrocarph(scheff.) Boerl,) Sebagai Tabir Surya. Traditional Medicine Journal, Vol. 18 No. 2.

Syah, A. N.A. 2006. Taklukan Penyakit Dengan Teh Hijau. Depok: PT Agro Media Pustaka. Utami, S.P. 2015. Formulasi Sediaan Krim Tipe M/A dari Minyak Atsiri (Pogostemon cablin B.) dan Uji Aktivitas Repelan. Skripsi.

Wulandari, P. 2016. Uji Stabilitas Fisik dan Kimia Sediaan Krim Ekstrak Etanol Tumbuhan Paku (Nephrolepis falcate (Cav.) C. Chr.).Skripsi.

Yulianti, R. 2015. Formulasi Krim Anti Jerawat Kombinasi Ekstrak Daun Sirsak (Annona muricata L.) dan Daun Jambu Biji (Psidium guajava L.). Jurnal Kesehatan. Vol 14 No. 1 